\title{
Sikkim: An Insurgency Free State
}

\author{
Ashay Anand
}

\begin{abstract}
Sikkim is the only insurgency free state in North- East India apart from Meghalaya. The paper attempts to determine the factors that have led to Sikkim being free of insurgency while the entire area is infested by insurgent groups. Owing to the relative lack of analytical research on the State, the question has never been answered before. Sikkim has turned out to be the only state in the North-Eastern region which has no history of insurgency. As such it may act as a medicine for the problem of insurgency in the North-East despite marked differences in the conditions of Sikkim and other North-Eastern states. The 'Sikkim Approach' to solve the problem of Insurgency might prove very useful in the long run. The Sikkim story is a story of development and security which should be the ideal approach of governance in any state. If this approach is successfully adopted in other states as well the problem of insurgency might soon be a thing of the past.

The 'North-Eastern Region' of India is one of the most disturbed regions of India. Ethinically diverse it is severely gripped by insurgency and terrorist movements and is a home to more than 200 insurgent groups. ${ }^{I}$ The region comprises of the seven contiguous sister-states and their brother i.e. Sikkim. Unlike the turbulent sister-states, Sikkim was always a peaceful state since its incorporation in India. Sikkim, till date, has not witnessed any insurgency movements. The lone incident of spill over of Insurgency from neighbouring states has been the arrest of National Democratic Front of Bodoland (NDFB) vice-president Dhiren Boro alias Bipul Sonowal on $1^{\text {st }}$ January 2003 along with his wife, two children and two body guards. ${ }^{2}$ Apart from this sole incident Sikkim has never had any reported incidents of Insurgency.
\end{abstract}

\section{Sikkim: Strategically Insulated From Insurgency}

Sikkim was incorporated in India on 16 May, 1975 as the twenty second state of the Indian nation when the people of Sikkim opted for a referendum abolishing monarchy and merger with India ${ }^{3}$. For twenty eight years Sikkim remained one of the several issues creating tension between India and China, with the Chinese leadership declining to acknowledge Sikkim as a part of India. Sikkim was inducted quite recently in the "North- Eastern Council' ${ }^{4}$ after China eventually recognized Sikkim as an Indian state in 2003, on the condition that India accepted the Tibet Autonomous Region as a part of China ${ }^{5}$. One of the major reasons for peace in Sikkim has been its importance to both India and China. Sikkim's strategic importance to the Indian state has led to many parts of Sikkim being closed to outsiders and a sizeable army deployed in the state to protect Indian borders. This special position has been a deterrent to the spread of insurgency in the state. The armed forces have come in handy for maintaining law and order and in the prevention of insurgency. Moreover China's special interest in Sikkim till 2003 was also instrumental in deterring the insurgent groups from infesting the state. The patronage available to most of the Insurgent groups from outside the Indian state and their external links have helped Insurgency survive in the North- East. The Insurgent groups look towards nations such as Myanmar, Bangladesh, Bhutan, Nepal and China which have contiguous borders with India for transport of ammunitions, funds and refuge during the times of duress. As such the insurgent groups could not have risked the Chinese wrath by carrying out activities in a territory which China claimed to be disputed. ${ }^{6}$ As such Sikkim enjoyed a contemporary era of marked peace and stability.

\footnotetext{
${ }^{1}$ Government of India, Ministry of Home Affairs, Annual Report 2007-08

${ }^{2}$ CDPS, Centre for Peace Studies, Website for the Centre of Peace Studies, Govt. of India. http://cdpsindia.org/sikkim_insurgency.asp

"About Sikkim". Official website of the Government of Sikkim. http://sikkim.gov.in/ASP/Miscc/aboutsikkim.htm.

${ }^{4}$ The State of Sikkim, with its official inclusion into the North Eastern Council (NEC), the region's head funding and development agency, is now considered the eighth state of the Northeast region. For details see, <http://necouncil.nic.in/>.

${ }^{5} \wedge$ "India and China agree over Tibet". BBC News. 24 June 2003. http://news.bbc.co.uk/2/hi/south_asia/3015840.stm.

${ }^{6}$ According to the views of Dr. Satish Jha, Associate Professor of Political Science, Ram Lal Anand (Eve.) College, University of Delhi; Based on his Lectures on Sino- Indian Relations from 1950-2011.
} 


\section{Geographical And Social Detterent To The Spread Of Insurgency In Sikkim}

With 6, 07,000 inhabitants and 7,096 sq. km area ${ }^{7}$, Sikkim is the second smallest state in India after Goa and the least populous. Sikkim is also one of the least densely populated Indian states, with only 86 persons per square kilometre. Despite of its high population growth rate, averaging 12.36\% between 2001 and 2011, Sikkim remains sparsely populated. With 50,000 inhabitants, the capital Gangtok is the only significant town in the mostly rural state; the urban population in Sikkim constitutes around $11.06 \%$ of the total ${ }^{8}$. This makes Sikkim a rural sparsely populated state with a sizeable contigent of armed forces which is undesirable for any insurgent outfit to prosper in the state or to use it as a base to carry out insurgent activities in other states. The low population makes it difficult for insurgents to mix in easily with the common inhabitants as compared to a densely populated state like Assam. The risk of being spotted easily keeps the stakes too high for the insurgent groups to operate in the state. To add to this factor, the per capita income in Sikkim stands at Rs. 11,356, which is one of the highest in the country ${ }^{9}$. A higher per capita income suggests that the people of Sikkim are financially well off keeping the chances of their economic contentment high and gives them lesser reasons to have resentment against government policies.

Like the "seven sisters" Sikkim is also ethnically diverse and the Sikkimese populace derives its ethnic origins from Nepali, Bhutias, Lepchas and Tibetans. The Nepalese constitute a large majority of the Sikkim's population followed by Bhutias, Lepchas and the Tibetans who fled from Tibet after the Chinese annexation. Migrant resident communities include Biharis, Bengalis and Marwaris, who are prominent in commerce in South Sikkim and Gangtok ${ }^{10}$. Despite this ethnic diversity Sikkim never ever had a recorded history of mass violence or insurgency. In fact it is also listed in the Guinness book of world records as the violence free state. The ethnic groups have largely remained at peace with each other and there is no recorded history of bad blood between these groups unlike many of the ethnic tribes in the other North- Eastern states. The Sikkimese people have been generally supportive of the Indian government and barring the 'Greater Nepal Movement' in the recent years there has been no recorded instances of antagonisms against the established order in Sikkim. The 'Greater Nepal movement' has proposed that the territory of Sikkim be returned to Nepal as part of the restitution of Nepalese lands seized by the British in the $19^{\text {th }}$ and $20^{\text {th }}$ centuries. The supporters of the movement claim that, as the 1815 Sugauli Treaty was rescinded by the 1950 Indo-Nepal Treaty of Peace and Friendship, the area comprising the state of Sikkim legally belongs to Nepal. However, this has largely been a fringe viewpoint, lacking widespread support.

\section{Steps Taken By The Government To Keep Sikkim Free From Insurgency}

Apart from strategic, geographical and social factors that have helped keep insurgency at bay in Sikkim the Indian government has taken huge steps to keep Sikkim free from Insurgency. The Indian government has kept a watchful eye on the Insurgency situation in the North- East. Every aspect of insurgency is being examined to get rid of this menace. The Ministry of Home Affairs has taken several innovative steps to counter insurgency in the North- East in the past two decades. A three- pronged approach of tackling insurgents by developing infrastructure and promoting economic growth, strengthening security and combating insurgency with an iron hand and rehabilitation and negotiations with insurgency groups seeking peace has been adopted. One such approach has been to scuttle the source of funds to the insurgent groups. In this regard 2 NGO's have been put under surveillance by the Union Home Ministry from Sikkim for their links with Insurgent groups active in the region ${ }^{11}$. NGO's have been widely used by Insurgent groups to funnel funds for terrorist and insurgency activities.

To strengthen Sikkim's security Sikkim has been granted 46.9 million rupees by the centre between 2000-2003 for the modernization of police forces. Although this amount seems to be miniscule when compared to the grants received by Assam (1027.3 million) during the same period, they are enough to give teeth to the police forces in a sparsely populated state such as Sikkim. ${ }^{12}$

In the last two and half decades, Sikkim's economy at macro level is growing at a steady rate. Real average growth rate from 2000-01 to 2006-07 stands at 7.8 per cent, which apparently looks very impressive. The contribution of primary sector towards Gross State Domestic Product (GSDP) is continuously falling while

\footnotetext{
Arjun Adlakha (April 1997). "Population Trends: India" (pdf). International brief. U.S. Department of Commerce. p. 5. http://www.census.gov/ipc/prod/ib-9701.pdf\#search=\%22india\%20state\%20population\%22.

8 "Sikkim at a glance". Department of Information and Public Relations, Government of Sikkim. 29 September 2005 http://web.archive.org/web/20051031000351/http://www.sikkimipr.org/GENERAL/STATS/sikkimataglance.htm.

9 "People of Sikkim". Department of Information and Public Relations, Government of Sikkim. 29 September 2005.

${ }^{10}$ Clarence, Maloney (1974). Peoples of South Asia. Holt, Rinehart and Winston. p. 409. ISBN 0-03-084969-1.

${ }^{11}$ This included 323 NGOs in Meghalaya, 197 in Manipur, 151 in Assam, 82 in Nagaland, 69

in Tripura and 2 in Sikkim. The Telegraph, Calcutta, May 24, 2003.

${ }_{12}$ Ministry of Home Affairs, Annual Report 2002-2003, Government of India, New Delhi.
} 
that of services is increasing. This trend resembles development pattern experienced by the developed economies. However, a close look at real growth figures reveals that growth is more pronounced in the sectors where government is playing a direct role. The phenomenal growth of public administration and other services suggest that government remains the sole provider of jobs in the State. ${ }^{13}$ The government's efforts in boosting the state's economy have been largely successful. By developing the backbone of economy the government has not only kept insurgency at bay but has also made the economy capable of taking care of itself in the wake of peace and stability. This has led to a paradigm shift in the trend of economic growth. Since 1996-97 the growth rate of trade, hotels and restaurants has started picking up and is growing consistently. In addition to this, trade and commerce, banking and insurance are also growing very satisfactorily. From 2000-01, transport and communication have also been consistently growing. ${ }^{14}$

This may be portrayed as the much desired shift from government sponsored growth story to rapid expansion of tourism activities. This would help in sustaining overall growth of the State's economy in the future and help in continuing progress and development.

After Sikkim's incorporation in India in 1975, serious efforts were made to create new avenues for livelihood outside agriculture without disturbing the rural fabric of the region. The most visible efforts were on the expansion of education and health care with the establishment of schools and hospitals across the State (Sankritayana 1991). A sharp increase was seen in the literacy rate of the state when compared to its corresponding figures during the years immediately following its incorporation. Progress in this respect has been achieved by spending a large part of the central grant to the State in the social sector. Creation of vast amount of human capital has been achieved within a short span of time. ${ }^{15}$ All this was achieved by government's will to boost Sikkim's economy.

The economic growth has brought a vast change in the life style of the Sikkimese people. They have better access to health care, education and other basic amenities than they had during the earlier decades. This is one of the major reasons for peace amongst the people of Sikkim. It has been a major boost to the government's idea of tackling Naxalism and Insurgency by promoting development. The high literacy rate and the spread of education has also been an important factor in keeping Sikkim free from Insurgency.

\section{Keeping Sikkim Secure}

Every state in the region excepting Sikkim is currently affected by some form of insurgent violence. ${ }^{16}$ Keeping this in mind the government has abstained from adopting any callous approach that might lead to a debacle. To strengthen border security road links totaling $608 \mathrm{~km}$. in the border areas in the States of Jammu \& Kashmir, Himachal Pradesh, Uttarakhand, Sikkim and Arunachal Pradesh at an estimated cost of Rs.912 crore are being constructed by the Indian government. To counter insurgency 40 India reserve battalions were sanctioned to the North- Eastern states out of which 1 battalion was sanctioned for Sikkim. In addition to this Sikkim has a total authorised strength for police force deployment of 32 battalions of which all of them are in actual deployment. ${ }^{17}$ These efforts have been highly successful. During the year 2007 Sikkim reported no violence. The previous and subsequent years have been equally peaceful. Sikkim has turned out to be a model of peace and stability for the North- Eastern region.

\section{Conclusion}

Sikkim has turned out to be the only state in the North- Eastern region which has no history of insurgency. As such it may act as a medicine for the problem of insurgency in the North- East despite marked differences in the conditions of Sikkim and other North- Eastern states. The 'Sikkim Approach' to solve the problem of Insurgency might prove very useful in the long run. The Sikkim story is a story of development and security which should be the ideal approach of governance in any state. If this approach is successfully adopted in other states as well the problem of insurgency might soon be a thing of the past.

(A section of this article regarding the impact of Sino-Indian relations on the peace and stability of Sikkim has been heavily drawn from the view of Dr. Satish Jha who is an Associate Professor of Political Science at Ram Lal Anand (Eve.) College, University of Delhi)

\footnotetext{
${ }^{13}$ Anjan Chakrabarti; Tourism in Sikkim: Quest for a self- reliant Economy; The NEHU journal, Vol. VII, No.1, 2009, p.89

${ }^{14}$ Anjan Chakrabarti; Tourism in Sikkim: Quest for a self- reliant Economy; The NEHU journal, Vol. VII, No.1, 2009, p.90

${ }^{15}$ Anjan Chakrabarti; Tourism in Sikkim: Quest for a self- reliant Economy; The NEHU journal, Vol. VII, No.1, 2009, pp.89,90

${ }^{16}$ Subir Bhaumik; Insurgencies in India's North- East: Conflict, Co-option and Change; Working Papers, No.10, July 2007, East West Center, Washington

${ }^{17}$ Government of India, Ministry of Home Affairs Annual Report 2007-08
} 


\section{References}

[1]. Government of India, Ministry of Home Affairs Annual Report 2007-08.

[2]. Anjan Chakrabarti; Tourism in Sikkim: Quest for a self- reliant Economy; The NEHU journal, Vol. VII, No.1, 2009, pp.89,90

[3]. Subir Bhaumik; Insurgencies in India's North- East: Conflict, Co-option and Change; Working Papers, No.10, July 2007, East West Center, Washington

[4]. Ministry of Home Affairs, Annual Report 2002-2003, Government of India, New Delhi.

[5]. "Sikkim at a glance". Department of Information and Public Relations, Government of Sikkim. 29 September 2005. http://web.archive.org/web/20051031000351/http://www.sikkimipr.org/GENERAL/STATS/sikkimataglance.htm.

[6]. "People of Sikkim". Department of Information and Public Relations, Government of Sikkim. 29 September 2005.

[7]. Clarence, Maloney (1974). Peoples of South Asia. Holt, Rinehart and Winston. p. 409. ISBN 0-03-084969-1.

[8]. "India and China agree over Tibet". BBC News. 24 June 2003. http://news.bbc.co.uk/2/hi/south_asia/3015840.stm.

[9]. Arjun Adlakha (April 1997). "Population Trends: India" (pdf). International brief. U.S. Department of Commerce. p. 5. http://www.census.gov/ipc/prod/ib9701.pdf\#search=\%22india\%20state\%20population\%22.

[10]. CDPS, Centre for Peace Studies, Website for the Centre of Peace Studies, Govt. of India. http://cdpsindia.org/sikkim_insurgency.asp

[11]. "About Sikkim". Official website of the Government of Sikkim. http://sikkim.gov.in/ASP/Miscc/aboutsikkim.htm.

[12]. "Innovative Methods in Fighting Insurgency in North- East India", Ministry of Home Affairs, Government of India 